\title{
ANALISIS KONDUKSI TERMAL JARINGAN SAPI DALAM INTERVAL WAKTU PENYERAPAN RADIASI TERAHERTZ DARI MILIDETIK SAMPAI PIKODETIK MENGGUNAKAN KOMPUTASI BIOFISIKA
}

\author{
UsmanMalik $^{1}$, Merry Handayani ${ }^{1} *$, Walfred Tambunan ${ }^{1}$, Mhd Hamdi ${ }^{1}$ \\ ${ }^{\prime} J u r u s a n$ Fisika Fakultas Matematika dan Ilmu Pengetahuan Alam Universitas Riau Kampus Binawidya Pekanbaru, 28293 \\ *e-mail: hmerry92.mh@gmail.com
}

\begin{abstract}
Abstrak
Penelitian ini mensimulasikan persamaan diferensial parsial konduksi panas 1-D untuk memprediksi model distribusi temperature jaringan biologis sapi seperti kulit, lemak, tumor dan otot selama penyerapan radiasi Terahertz sebagai fungsi posisi pada kedalaman dan sebagai fungsi waktu dari mili detik sampai piko detik. Pemodelan pola-pola temperature jaringan dari penyerapan radiasi Terahertz dikaji secara teoritis dengan metode komputasi biofisika menggunakan software Wolfam Mathematica 9. Penggunaan parameter-parameter fisis konduksi panas pada kedalaman jaringan biologis sapi dari 0,1 mm sampai 0,3 mm, dan daya penyerapan radiasi Terahertz dari $2,5 \mathrm{~mW}$ sampai $5,5 \mathrm{~mW}$ dengan rentang frekuensi dari $0,1 \mathrm{THz}$ sampai $1 \mathrm{THz}$. Hasil radiasi ini mengindikasikan penyerapan radiasi Terahertz dengan variasi daya yang memiliki karakteristik tersendiri dalam waktu mili detik sampai piko detik. Daya penyerapan radiasi Terahertz yang besar dan waktu yang besar akan menghasilkan temperatur yang tinggi pada masing-masing jaringan bilogis sapi. Temperatur sebagai fungsi kedalaman dipengaruhi oleh kandungan air di dalam jaringan biologis sapi, kandungan air penyusun jaringan yang kental pada waktu yang besar akan menghasilkan temperatur yang kecil. Perbandingan diantara pemodelan dan eksperimen menunjukkan bahwa prediksi temperatur transfer panas radiasi Terahertz cukup akurat dengan ketidakpastian kesalahan penyebaran untuk parameter-parameter yang diturunkan sebesar $0,8 \%$.
\end{abstract}

Kata Kunci: Pemodelan komputer analog, Distribusi termal, Jaringan sapi, Penyerapan, Radiasi Terahertz

\begin{abstract}
[Title : Analysis Thermal Conduction in The Cow Tissue during Absorption of Teraherz Radiation From Milliseconds To Picoseconds using Biophysical Computation This research simulates the partial differential equation of 1-D thermal conduction to predict distribution model of cow's biological tissue temperature such as skin, fat, tumor, and muscle during Terahertz radiation absorption as a function of depth position and as a function of time from millisecond to picosecond. The modeling of tissue temperature patterns from Terahertz radiation absorption was examined theoretically with biophysical computation method using software Wolfram Mathematica 9. The utilization of physical parameters thermal conduction at the depth of cow's biological tissue from $0,1 \mathrm{~mm}$ to $0,3 \mathrm{~mm}$, and Terahertz radiation absorption power from 2,5 $\mathrm{mW}$ to $5,5 \mathrm{~mW}$ with frequency range from 0,1 Thz to $1 \mathrm{Thz}$. The result of this radiation indicatid that Terahertz radiation absorption with power variation has its own characteristics in millisecond to picosecond. High power and large amount of time of the Terahertz radiation absorption will produce a high temperature in each cow's biological tissue. The temperature as a function of depth is influenced by the water in cow's biological tissue, the thick water as the tissue constituent in a large amount of time will produce a small temperature. Comparison between modeling and experiment showed that prediction of Terahertz temperature thermal radiation transfer is quite accurate to the uncertainty of the deployment error for derived parameters is $0.8 \%$.
\end{abstract}

Keywords: Modeling computer analog, Terahertz radiation, Thermal distribution, Absorption, Tissue cow's 


\section{PENDAHULUAN}

Distribusi temperature secara konduksi melalui medium merupakan suatu proses fisis yang sering terjadi dalam fisika. Perpindahan panas secara konduksi terjadi akibat perpindahan energy dari benda yang bersuhu tinggi ke benda yang suhunya lebih rendah karena adanya perbedaan suhu diantara benda atau material (Kern, 1950).

Panas dari tubuh harus dikonduksi terlebih dahulu ke udara maupun ke air untuk kemudian dibawa melalui aliran konveksi. Ketika suhu lingkungan lebih tinggi dari suhu tubuh, maka tubuhakan menerima panas karena pengaruh penyerapan radiasi Terahertz. Apabila tubuh tidak dapat melepaskan panas yang dihasilkan maka suhu tubuh akan terus meningkat (Ali, 2010).

Jaringan biologi memiliki medium dengan daya serap radiasi dan kandungan air yang berbeda mengakibatkan terjadinya interaksi radiasi Terahertz dengan jaringan biologi. Ketika radiasi Terahertz berinteraksi dengan tubuh mengalami proses termal yang dipengaruhi daya transfer panas dan densitas jaringan sehingga dapat ditentukan konduksi termal dari masing-masing jaringan biologi (Michael, 2003).

Radiasi Terahertz merupakan salah satu instrumen yang menggunakan prinsip spektroskopi untuk mendeteksi lokasi tumor atau kanker tanpa merusak jaringannya karena foton radiasi Terahertz tidak cukup energy untuk memutus ikatan kimia atau mengionisasi atom dan molekul. Ketika radiasi Terahertz berinteraksi dengan tubuh, beberapa radiasi direfleksikan, beberapa diserap dan beberapa ditransmisikan. Radiasi Terahertz dapat difokuskan sehingga mudah dikontrol, dan memiliki penyerapan radiasi hamburan rendah sehingga mampu mendeteksi sifat getaran molekul yang kuat (Ronne, 1997).

Gelombang Terahertz (THz) adalah bagian dari spectrum electromagnetic dengan panjang gelombang yang berada di antara spektrum infrared dan microwave. Wilayah Terahertz dalam spektrum elektromagnetik dalam rentang frekuensidari 0,1 $\mathrm{THz}$ sampai $1 \mathrm{THz}$. Perubahan wilayah intensitas radiasi Terahertz dengan kenaikan termal menunjukkan adanya penyerapan radiasi pada jaringan biologi (Fitzgerald, 2003).

\section{METODE}

Berikut ini diagram alir yang menunjukkan prosedur yang dilakukan dalam penelitianini:

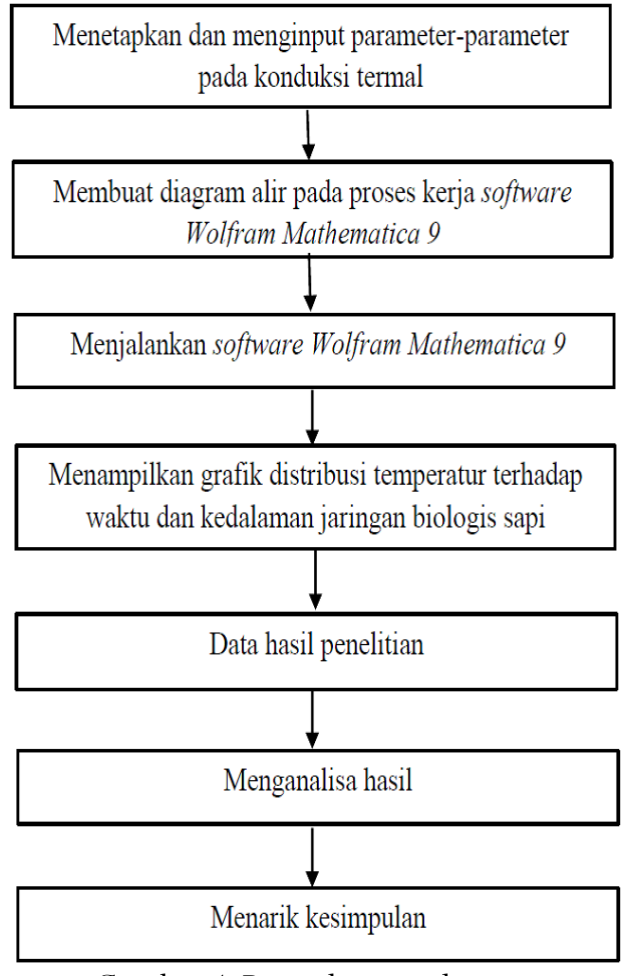

Gambar 1.Prosedur penelitian

Persamaan diferensial parsial konduksi panas 1-D diselesaikan secara teoritis berdasarkan syarat awal dan syarat batas yang berhingga seperti berikut ini:

$$
T(x, 0)=T(x, a)=T(b, t)=0, T(0, t)=T_{o}
$$

Sehingga didapatkan solusi konduksi termal 1-D sebagai berikut:

$$
T(x, t)=A e^{-\mu^{2}(K c / \rho C) t} e^{(-\mu x)}
$$

Pengaruh penyerapan radiasi Terahertz terhadap konduksi termal pada jaringan biologi berdasarkan persamaan berikut:

$$
\frac{\partial \mathrm{T}}{\partial \mathrm{t}}=-\alpha \frac{\partial^{2} \mathrm{~T}}{\partial \mathrm{x}^{2}}+\frac{\mathrm{P}}{4 \pi \delta^{2} \mu} \mathrm{e}^{-\mu(\mathrm{x} / \delta)}
$$

Berikut ini adalah diagram alir yang menunjukkan komputasi numeric terhadap potensial listrik:

Komputasi biofisika yang dilakukan menggunakan komputer analog dengan software Wolfram Mathemathica 9 


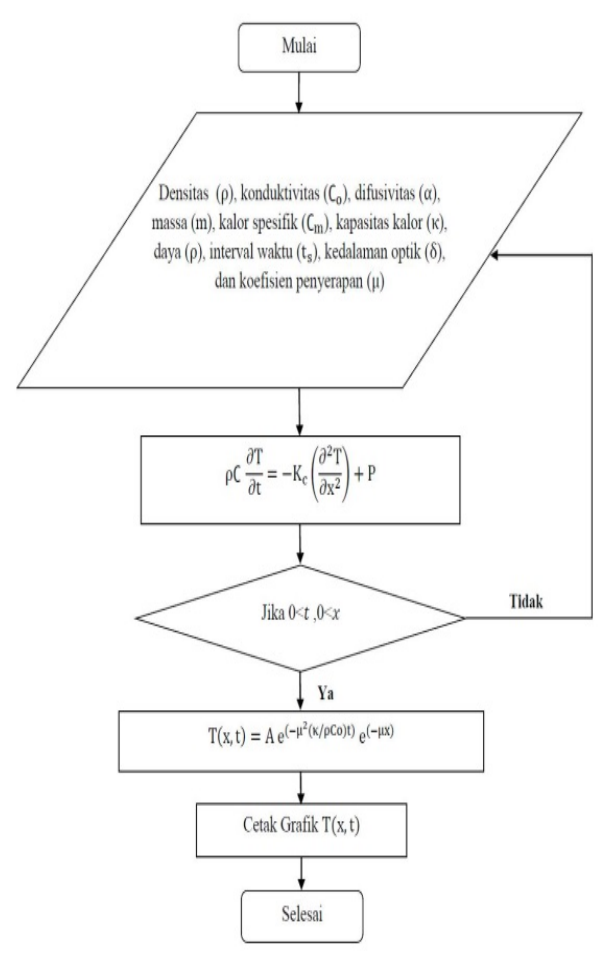

Gambar 2.Diagram alir konduksi termal

\section{HASIL DAN PEMBAHASAN}

\section{a. Penyerapan Radiasi THz Terhadap Konduksi Termal}

Penyerapan radiasi $\mathrm{THz}$ dalam jaringan biologis sapi pada Gambar 4.1 mengidentifikasi perubahan suhu pada masing-masing jaringan dari waktu mili detik sampai piko detik yang dilihat pada garis berwarna biru muda.

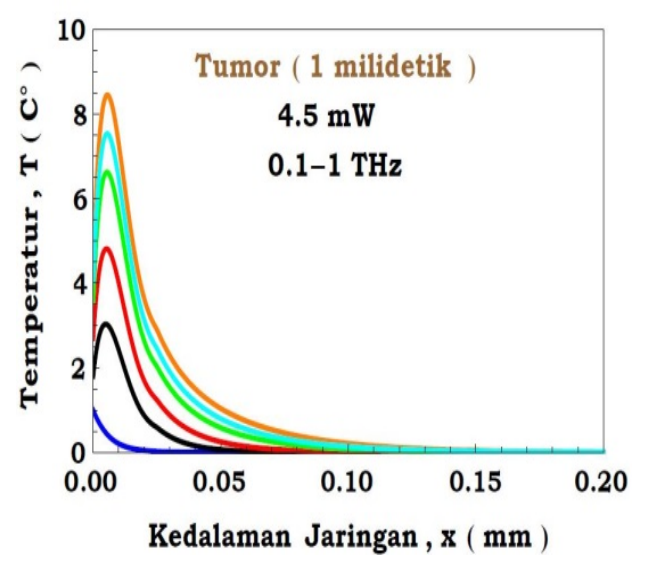

(a)

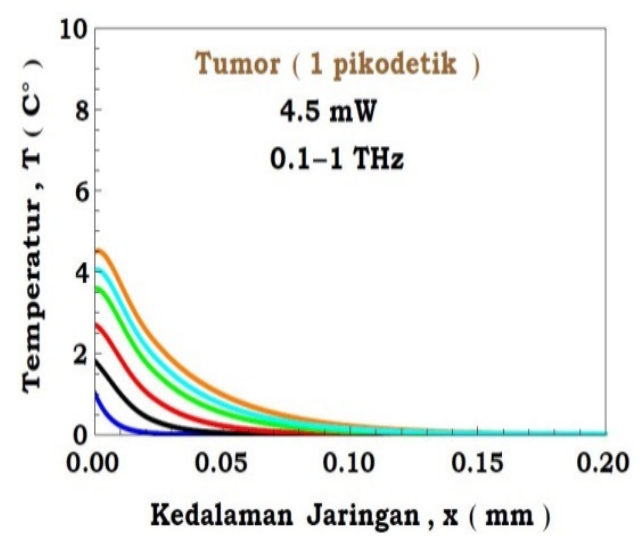

(b)

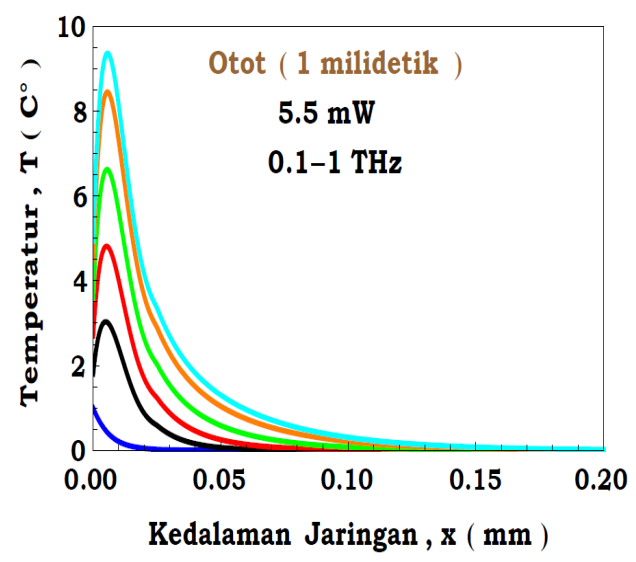

(c)

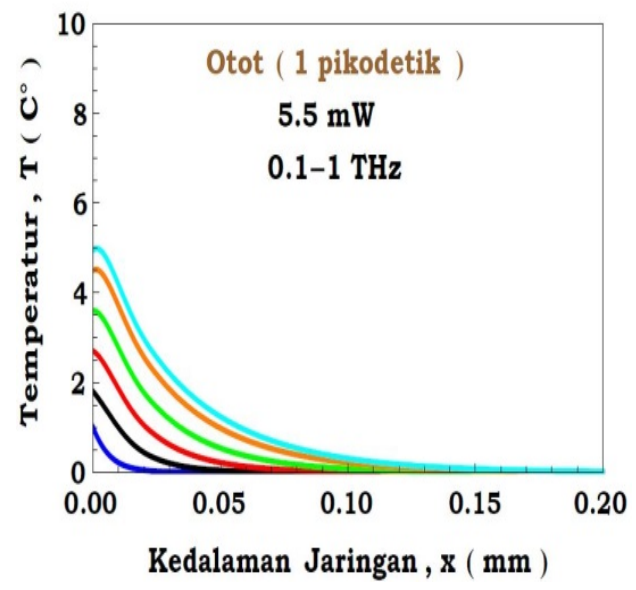

(d)

Gambar4.1 Perubahan temperatur yang dihasilkan dengan variasi densitas disetiap jaringan dan daya radiasi $\mathrm{THz}$ dalam durasi waktu mili detik sampai piko detik pada (a) tumor, dan (b) otot.

Variasi daya radiasi Terahertz yang besar dan waktu yang besar akan mempengaruhi perubahan temperatur. Sampel jaringan biologis sapi yang digunakan sebagai perbandingan yaitu jaringan 
abnormal atau tumor dan jaringan normal pada otot. Daya radiasi Terahertz yang diberikan pada tumor lebih rendah dibandingkan otot sehingga temperatur yang dihasilkan pada tumor lebih kecil. Perubahan temperatur pada daya yang sama dalam interval waktu yang berbeda pada tumor dan otot menunjukkan temperature yang tinggi pada waktu mili detik dan temperatur yang kecil pada waktu piko detik.

\section{b. Perbandingan Temperatur Eksperimen dan Pemodelan}

Perbandingan eksperimen dan pemodelan pada perubahan suhu dengan interval waktu mili detik dan piko detik yang digunakan pada jaringan dapat dilihat padaTabel 4.4.

\begin{tabular}{|c|c|c|c|c|c|c|}
\hline \multirow{3}{*}{$\begin{array}{l}\text { Jaringan } \\
\text { Biologis }\end{array}$} & \multirow{3}{*}{$\begin{array}{c}\text { Kedalaman } \\
\text { Jaringan } \\
(\mathrm{mm})\end{array}$} & \multicolumn{4}{|c|}{ Temperatur $\left({ }^{\circ} \mathrm{C}\right)$} & \multirow{3}{*}{$\begin{array}{c}\text { Persentase } \\
\text { Kesalahan } \\
(\%)\end{array}$} \\
\hline & & \multicolumn{2}{|c|}{ Eksperimen } & \multicolumn{2}{|c|}{ Pemodelan } & \\
\hline & & $\begin{array}{c}\text { Milidetik } \\
(\mathrm{s})\end{array}$ & $\begin{array}{c}\text { Pikodetik } \\
(\mathrm{s})\end{array}$ & $\begin{array}{c}\text { Milidetik } \\
(\mathrm{s})\end{array}$ & $\begin{array}{c}\text { Pikodetik } \\
(\mathrm{s})\end{array}$ & \\
\hline Kullit & 0,20 & 4,03 & 4,99 & 4,00 & 4,96 & 0,8 \\
\hline Lemak & 0,30 & 0,10 & 4,94 & 3,60 & 4,94 & 0,8 \\
\hline Tumor & 0,10 & 0,19 & 4,96 & 0,19 & 4,93 & 0,8 \\
\hline Otot & 0,15 & 0,60 & 4,94 & 0,60 & 4,91 & 0,8 \\
\hline
\end{tabular}

Mengindikasikan persentase kesalahan model dan eksperimen pada masing-masing jaringan yaitu kulit, lemak, tumor dan otot bernilai 0,8\%.

\section{KESIMPULAN}

Berdasarkan hasil penelitian yang telah dilakukan dapat disimpulkan sebagai berikut:

1.Pemodelan daya penyerapan radiasi Terahertz terhadap temperatur pada jaringan sapi menghasilkan temperatur yang lebih tinggi untuk 1 mili detik dikarenakan energi yang dikeluarkan pada radiasi Terahertz lebih besar yang mengakibatkan masing-masing jaringan melepaskan kalor atau panas yang tinggi. Semakin besar daya dan waktu penyerapan radiasi Terahertz yang di berikan pada jaringan maka akan menghasilkan temperatur yang tinggi.
2. Pemodelan 1-D konduksi termal pada waktu1 piko detik menghasilkan temperatur yang lebih tinggi karena waktu pada piko detik lebih dekat dengan frekuensi air sehingga cepat rambat radiasi Terahertz yang diserap dalam jaringan pada waktu piko detik lebih cepat dan energy radiasi Terahertz yang dipancarkan lebih besar.

3. Pemodelan temperatur jaringan biologis pada sapi dengan metode komputasi biofisika memiliki persentase kesalahan sebesar $0.8 \%$ terhadap literatur hasil eksperimen.

\section{DAFTAR PUSTAKA}

Kern, D. Q. 1950. Proses Heat Transfer. McGrawHill Book Company: New York.

Ali J. 2010. Transition of Diatomic Molecular Oscillator Process in $\mathrm{THz}$ Region.Proceeding of ICEM: 233-235.

Michael F. Modest. 2003. Radiation Heat Transfer. Second Edition Copyright Elsevier Science (USA).

Fitzgerald A.J. 2003. Catalogue of Human Tissue Optical Properties atTerahertz Frequencies.Journal of Biological Physics Kluwer Academic Publishers):123-128.

Ronne C. 1997. Investigation of The Temperature Dependence of Dielectric Relaxation in Liquid Water By $\mathrm{THz}$ Reflection Spectroscopy and Molecular Dynamics Simulation. J. Chem. Phys:107-108. 